\title{
PARAMETER POPULASI DAN TINGKAT PEMANFAATAN IKAN KUNIRAN (Upeneus sulphureus, Cuvier 1829) DI PERAIRAN SELAT MALAKA
}

\section{POPULATION PARAMETERS AND EXPLOITATION LEVEL OF SULPHUR GOATFISH (Upeneus sulphureus, Cuvier 1829) IN THE MALACCA STRAIT}

\author{
Nurulludin ${ }^{1 \#}$, Titin Siswantining ${ }^{1}$, Muhammad Taufik ${ }^{2}$, dan Rudy Masuswo Purwoko ${ }^{3}$ \\ ${ }^{1}$ Fakultas Matematika dan Ilmu Pengetahuan Alam, Universitas Indonesia \\ Jl. Prof. Dr. Sudjono D Pusponegoro Kampus UI, Depok \\ ${ }^{2}$ Balai Riset Perikanan Laut, Cibinong-Jawa Barat \\ Jl. Raya Bogor Km.47, Nanggewer Mekar, Cibinong, Bogor \\ ${ }^{3}$ Pusat Riset Perikanan \\ Jl. Pasir Putih II, Ancol Timur, Jakarta Utara \\ E-mail: nurulludin@kkp.go.id
}

(Diterima: 13 Februari 2020; Diterima setelah perbaikan: 3 Juni 2020; Disetujui: 3 Juni 2020)

\begin{abstract}
ABSTRAK
Sumberdaya ikan kuniran (Upeneus sulphureus) di Selat Malaka telah dieksploitasi sejak lama dengan alat tangkap pukat tarik, terutama sebelum adanya moratorium pelarangan alat tangkap trawl dan sejenisnya. Penelitian dilaksanakan pada bulan Januari - November 2014 di Perairan Selat Malaka. Pengukuran panjang cagak ikan kuniran diambil secara acak terhadap 2.694 sampel yang dilakukan di PPS Belawan. Tujuan penelitian ini adalah untuk menganalisis beberapa parameter pertumbuhan populasi ikan kuniran (Upeneus sulphureus) di Selat Malaka. Analisis data parameter populasi dianalisis menggunakan FAO-ICLARM Stock Assessement Tools (FISAT). Hasil analisis diperoleh beberapa parameter populasi ikan kuniran dengan koefisien pertumbuhan (K) sebesar 0,80 per tahun, (L') 21,0 cm, (M) 1,73 per tahun (F) 2,51 per tahun, dan E 0,59 per tahun. Penambahan baru individu ke dalam populasi berlangsung sepanjang tahun dan mencapai puncaknya terjadi pada akhir musim timur (Juni - Agustus) sampai musim peralihan II (September Nopember). Pemanfaatan ikan kuniran di perairan Selat Malaka sebelum moratorium pelarangan pukat tarik dalam kondisi jenuh (Fully exploited).
\end{abstract}

KATA KUNCI: Dinamika populasi; penangkapan; pukat tarik; kuniran; moratorium

\begin{abstract}
The exploitation of Malacca Strait fish resources has been going on for a long time with the seine net fishing gears especially before the moratorium. The research was conducted in January to November 2014 in the waters of the Malacca Strait. Measurement of the length of the sulphur goatfish was taken randomly to 2,694 samples conducted in Belawan Fishing Port. The purpose of this research was to analyze some growth parameter of fish population of sulphur goatfish (Upeneus sulphureus) caught in Malacca Strait. Analysis of population parameter data conducted using FISAT software (FAO-ICLARM Stock Assessement Tools). The analysis results obtained several parameters of sulphur goatfish population with growth coefficient (K) of 0.80 per year, (L") $21.0 \mathrm{~cm}$, (M) 1.73 per year (F) 2.51 per year, and E 0.59 per year. Recruitment occurred throughout the year with peak recruitment was occurred at the end of east season (June - August) until transitional period II (September - November). Exploitation of sulphur goatfish in the Strait of Malacca before moratorium is fully exploited.
\end{abstract}

KEYWORDS: Dinamic population; fishing; seine net; sulphur goatfish; moratorium

\footnotetext{
\# Korespondensi: Fakultas Matematika dan Ilmu Pengetahuan

Alam, Universitas Indonesia

E-mail: nurulludin@kkp.go.id
} 


\section{PENDAHULUAN}

Selat Malaka merupakan perairan yang sangat penting dalam menunjang perkembangan perikanan laut di perairan teritorial maupun di perairan ZEE. Propinsi Sumatera Utara termasuk salah satu bagian wilayah pengelolaan perikanan - Republik Indonesia (WPP-RI) 571 (Selat Malaka) yang memiliki potensi produksi sumber daya perikanan tangkap cukup tinggi. Beberapa kondisi geografis yang menjadikan perairan Selat Malaka merupakan daerah yang kaya akan sumber daya ikan yaitu lingkungan pada bagian utara dipengaruhi oleh Laut Andaman, sedangkan pada bagian selatan dipengaruhi oleh masuknya aliran sungai yang terdapat di wilayah Sumatera Utara, Riau, dan Malaysia terutama saat musim hujan (Hariati et al., 2000).

Peraturan Menteri Kelautan dan Perikanan Republik Indonesia Nomor 02/PERMEN-KP/2015 tentang larangan penggunaan pukat hela pukat Tarik (seine nets) di semua WPP-RI memiliki dampak yang positif dan negatif. Kondisi sumberdaya ikan dan habitatnya diharapkan akan pulih, meskipun penerapan permen ini akan berdampak terhadap pengusaha ikan setempat.

Ikan kuniran (Upeneus sulphureus) merupakan salah satu tangkapan dominan dari alat tangkap pukat ikan di Selat Malaka. Alat tangkap ini merupakan alat tangkap yang paling efektif menangkap ikan kuniran di lokasi Selat Malaka. Basis pendaratan ikan berada pada Pelabuhan Belawan. Alat tangkap ini menangkap semua ukuran ikan kuniran, sehingga dibutuhkan penelitian tentang parameternya. Sulistiono (2012) mengemukakan bahwa informasi biologi ikan penting dipelajari karena menentukan kelangsungan hidup ikan di perairan. Penelitian yang pernah dilakukan di Indonesia di antaranya di Teluk Kwandang (Fahmi \& Adrim, 2002), di Kendari (Asriyana et al., 2009); di Laut Jawa (Sumiono \& Nuraini, 2007; Kembaren \& Ernawati, 2011; Iswara et al., 2014; Azizah et al., 2015).

Tulisan ini bertujuan untuk menganalisis beberapa parameter populasi ikan kuniran (Upeneus sulphureus) di Selat Malaka, seperti sebaran panjang ikan, panjang pertama kali tertangkap, tingkat pertumbuhan, laju kematian, dan laju eksploitasi sebagai bahan dalam pengelolaan sumber daya ikan.

\section{BAHAN DAN METODE}

Pengukuran data frekuensi panjang ikan dilakukan dari bulan Januari sampai November 2014. Pengambilan contoh ikan diambil dari kapal pukat ikan yang melakukan bongkar muatan di PPS Belawan.

Pengukuran ikan berdasarkan panjang cagak (FL) dengan menggunakan kertas ukur dengan terlebih dahulu mensortir spesies ikan kuniran (Upeneus sulphureus). Pengambilan data ukuran ikan sebanyak 200 ekor ikan dari berbagai keranjang basket hasil tangkapan kapal secara acak dalam setiap bulan (Potier \& Sadhotomo, 1991).

\section{Pendugaan rata-rata panjang ikan kuniran tertangkap (LC)}

Data frekuensi panjang yang terkumpul diaplikasikan untuk perkiraan rata-rata ukuran ikan yang tertangkap (Lc). Pendugaan rata-rata panjang tertangkap dilakukan dengan membuat grafik hubungan antara panjang ikan (sumbu X) dengan jumlah ikan (sumbu Y) sehingga diperoleh kurva berbentuk S. Nilai length at first capture yaitu panjang pada $50 \%$ pertama kali tertangkap dihitung dengan persamaan sebagai berikut (Sparre \& Venema, 1999) :

$$
\begin{gathered}
S_{L} \text { est }=\frac{1}{1+\exp \left(S_{1}-S_{2}{ }^{*}\right)} \\
\operatorname{Ln}\left[\frac{1}{S L}-1\right]=S_{1}-S_{2}{ }^{*} L \\
L_{50 \%}=\frac{S_{1}}{S_{2}}
\end{gathered}
$$

dimana :

SL $\quad=$ kurva logistik;

$\mathrm{S}_{1}$ dan $\mathrm{S}_{2} \quad$ = konstanta pada rumus kurva logistik

Pendugaan rata-rata panjang pertama kali matang gonad (Lm)

Pendugaan rata-rata panjang pertama kali matang gonad (length at first maturity) dilakukan sesuai dengan prosedur penghitungan yang dilakukan Udupa (1986), melalui rumus :

$$
\mathrm{m}=\mathrm{Xk}+\mathrm{X} / 2-\left(\mathrm{X} \sum \mathrm{pi}\right)
$$

dimana :

$\mathrm{m}=\log$ ukuran ikan saat pertama matang ovarium

$\mathrm{Xk}=\log$ ukuran ikan di mana $100 \%$ ikan sampel sudah matang

$\mathrm{X}=$ selang log ukuran (log size increment)

$\mathrm{Pi}=$ proporsi ikan matang pada kelompok ke-i

Rata-rata ukuran ikan pertama matang ovarium diperoleh dari nilai antilog $(\mathrm{m})$.

\section{Pendugaan parameter pertumbuhan ikan kuniran}

Pendugaan nilai koefesien pertumbuhan $\mathrm{L}_{\text {, }}$ dan $\mathrm{K}$ dilakukan menggunakan mencari pergerakan atau pergeseran bulanan modus ukuran panjang. Setiap modus diturunkan dengan metoda Battacharya (1967) 
dalam Sparre \& Venema, (1999), menggunakan software Fisat ELEFAN $I$, sedangkan $t_{0}$ diperoleh melalui persamaan Pauly (1980). Model pertumbuhan yang digunakan adalah model yang dikemukakan oleh Von Bertalanffy (Sparre \& Venema, 1999) dengan persamaan sebagai berikut:

$$
\mathrm{L}_{\mathrm{t}}=\mathrm{L}_{\infty}\left(1-\mathrm{e}^{-\mathrm{k}(\mathrm{t}-\mathrm{t} t)}\right)
$$

dimana :

$\mathrm{Lt}=$ Panjang ikan $(\mathrm{cm})$ pada umur $\mathrm{t}$ (bulan)

$\mathrm{L}_{\infty}=$ Panjang asimptot ikan $(\mathrm{cm})$

$\mathrm{K}=$ Koefisien pertumbuhan (per tahun)

$\mathrm{t}_{0}=$ Umur teoritis ikan pada saat panjangnya sama dengan nol (bulan)

$\mathrm{t}=$ Umur ikan (bulan)

\section{Mortalitas ikan kuniran}

Mortalitas dalam suatu kegiatan perikanan tangkap sangat penting untuk menganalisis dinamika populasi atau stok ikan.

a. Mortalitas alami (M) diduga dengan metode persamaan empiris Pauly (1980) dengan rumus :

$\operatorname{Ln} M=-0,0152-0,279^{*} \operatorname{Ln} \mathrm{L}_{\infty}+0,6543^{*} \operatorname{Ln} \mathrm{K}+0,4634 * \operatorname{Ln} \mathrm{T}$

\section{b. Mortalitas Total (Z)}

Pendugaan mortalitas total (Z), menggunakan metode Beverton dan Holt dalam (Sparre et al., 1989) yaitu:

$$
\mathrm{Z}=\mathrm{K} \frac{\mathrm{L} \infty-\overline{\mathrm{L}}}{\mathrm{L}-\mathrm{L}^{\prime}}
$$

dimana :

$\mathrm{K}=$ Koefisien laju pertumbuhan (per tahun)

$\mathrm{L} \infty=$ Panjang asimptotik kuniran $(\mathrm{cm}) \mathrm{FL}$

$\overline{\mathrm{L}}=$ Panjang rata - rata kuniran yang tertangkap $(\mathrm{cm})$

' = Batas terkecil ukuran kelas panjang kuniran yang tertangkap $(\mathrm{cm})$

c. Mortalitas Penangkapan (F) dengan Laju Eksploitasi (E) ikan kuniran

Dari hasil pendugaan nilai $Z$ dan $\mathrm{M}$, maka mortalitas penangkapan $(\mathrm{F})$ diperoleh dari persamaan;

$$
\mathrm{Z}=\mathrm{F}+\mathrm{M} \text { atau } \mathrm{F}=\mathrm{Z}-\mathrm{M}
$$

$$
\mathrm{E}=\mathrm{F} / \mathrm{Z}
$$

\section{Umur}

Nilai dugaan umur teoritis pada saat panjang ikan sama dengan nol $\left(\mathrm{t}_{0}\right)$ ikan kuniran diperoleh dengan menggunakan rumus (Pauly, 1980) yaitu :

$$
\begin{gathered}
\log \left(-\mathrm{t}_{0}\right)=-0.3922-0.2752 \log -1.038 \log \mathrm{K} \\
\mathrm{L}_{\mathrm{t}}=\mathrm{L}_{\infty}\left(1-\mathrm{e}^{-\mathrm{k}(\mathrm{t}-\mathrm{t} 0)}\right)
\end{gathered}
$$

dimana :

$\mathrm{L}_{\mathrm{t}}=$ ukuran panjang ikan pada saat umur $\mathrm{t}$ tahun $(\mathrm{cm})$

$\mathrm{L}_{\infty}=$ panjang maksimum ikan yang dapat dicapai

$\mathrm{t}_{0}=$ umur ikan teoritis pada saat panjangnya $0 \mathrm{~cm}$

\section{Hasil per penambahan baru (Y/R)}

Analisa hasil per penambahan baru menggunakan rumus Beverton \& Holt dalam Sparre \& Venemma (1999):

$$
\frac{Y}{R}=F * \exp [-M *(t c-t r)] * W \infty 0 *\left[\frac{1}{z}-\frac{3 S}{2+K}+\frac{3 s^{2}}{Z+2 K}-\frac{s^{3}}{Z+3 K}\right]
$$

dimana:

$\mathrm{S}=\exp \left\{-\mathrm{K}^{*}\left(\mathrm{t}_{\mathrm{c}}-\mathrm{t}_{0)}\right\}\right.$

$\mathrm{t}_{\mathrm{r}}=$ umur rekrutmen

$\mathrm{W}_{\infty}=$ bobot badan asimtotik

$\mathrm{Z}=$ Mortalitas total $(\mathrm{F}+\mathrm{M})$

HASIL DAN BAHASAN

\section{Rata - Rata Ukuran Ikan}

Sebaran frekuensi panjang ikan kuniran hasil tangkapan kapal pukat ikan di Belawan menyebar normal dengan dua modus. Panjang ikan terkecil yang tertangkap pada kisaran nilai tengah panjang cagak 6 $\mathrm{cm}$ dan terpanjang berkisar $20 \mathrm{~cm}$ dan perkiraan ukuran panjang yang petama tertangkap (Lc) sekitar $11,66 \mathrm{~cm}$ dan pertama kali matang gonad $(=\mathrm{Lm}) 12,9$ cm. (Gambar 1 dan 2).

Ikan kuniran memiliki panjang pertama kali tertangkap sebesar $11,66 \mathrm{~cm}$, sedangkan panjang pada saat pertama kali matang gonad $(\mathrm{Lm})$ sebesar $12,9 \mathrm{~cm}$ Fl. Nilai Lc $<$ Lm mengindikasikan bahwa ikan kuniran yang tertangkap pukat tarik di selat Malaka belum sempat memijah. Kondisi ini masih dianggap wajar mengingat rata - rata ukuran ikan yang tertangkap masih lebih besar dari setengah panjang infinitinya. Ukuran rata-rata tertangkap idealnya tidak lebih kecil dari setengah panjang infinitinya (Saputra et al., 2009). Panjang pertama kali matang gonad ikan kuniran di laut Jawa 9,87 cm panjang cagak (FL) (Kembaren \& Ernawati, 2011), $\mathrm{Lm}=10,2 \mathrm{~cm}$ FL (Pavlova et al.,

2014). 


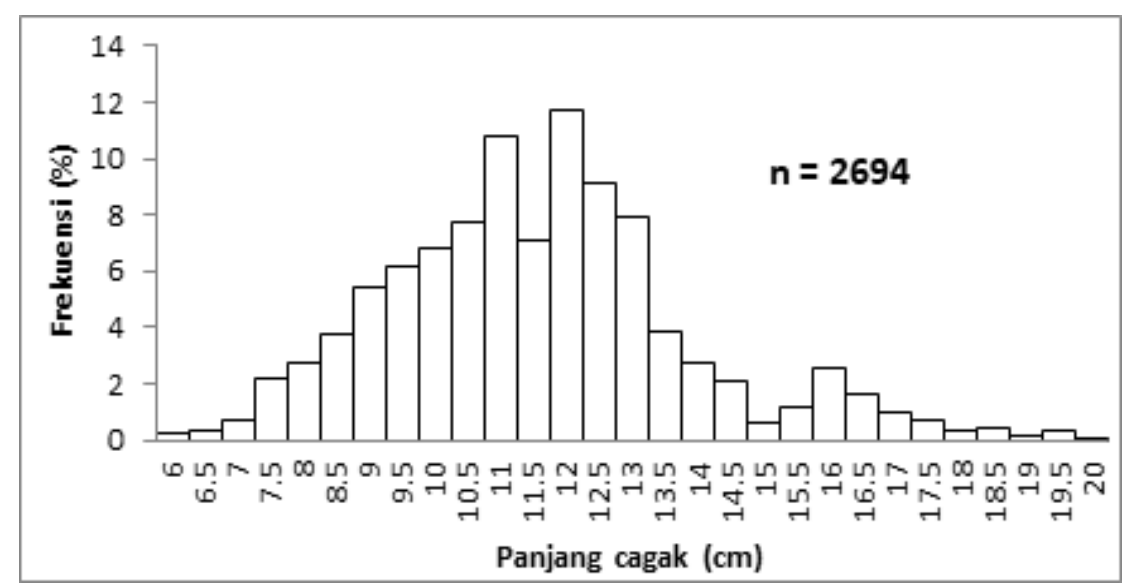

Gambar 1. Distribusi frekuensi panjang cagak ikan kuniran (Upeneus sulphureus).

Figure 1. The frequency distribution of fork length sulphur goatfish (Upeneus sulphureus).

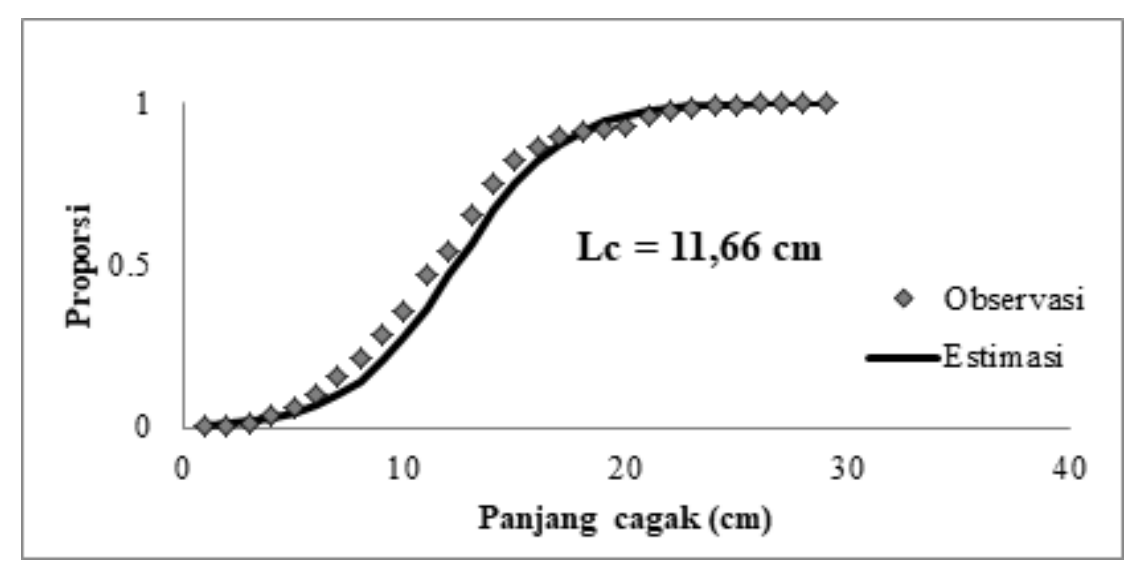

Gambar 2. Distribusi frekuensi panjang kumulatif ikan kuniran (Upeneus sulphureus).

Figure 2. The frequency distribution of cumulative length sulphur goatfish (Upeneus sulphureus).

Berdasarkan pada data panjang (FL) ikan kuniran (Upeneus sulphureus) yang diteliti dengan menggunakan rumus model Von Bertalanffy diperoleh nilai parameter pertumbuhan yaitu koefisien pertumbuhan (K) sebesar 0,80 per tahun, (Lo) 21,0 $\mathrm{cm}$, dan dugaan pemijahan terjadi pada bulan Oktober (Gambar 3). Koefisien laju pertumbuhan (K) yang tinggi diartikan bahwa ikan tersebut memerlukan waktu yang singkat untuk mencapai panjang maksimalnya (Sparre \& Venemma, 1999).

Pada penelitian tentang ikan kuniran di tempat lain diperoleh koefisien pertumbuhan $\mathrm{K}=0,66$ per tahun di Andhra, pantai Orissa, (Reuben et al., 1994), K= 0,64 per tahun (Nurulludin \& Prihatiningsih, 2014). Ikan dengan pertumbuhan cepat memiliki kemampuan untuk mempertahankan diri dari pengaruh lingkungan dan penangkapan. Ikan kuniran seperti halnya ikan petek yang memiliki pertumbuhan cepat akan merespon pengaruh eksternal tersebut dengan berbagai cara, di antaranya mempercepat waktu untuk memijah. Kembaren \& Ernawati (2011) bahwa di perairan Laut Jawa, ikan kuniran yang berukuran relatif kecil sudah matang gonad untuk mempertahankan keberadaan populasinya. Hal ini diduga disebabkan oleh tekanan penangkapan yang intensif.

Umur ikan kuniran pada saat panjang sama dengan nol $\left(\mathrm{t}_{0}\right)=-0,01055$, sehingga diperoleh persamaan adalah $\mathrm{Lt}=21\left(1-\mathrm{e}^{-1(t-0.01055)}\right)$. Dari persamaan tersebut dapat diduga rata-rata pertambahan panjang dari ikan kuniran setiap bulan sebesar 1,04 cm (Gambar 4). Pertambahan panjang paling besar terjadi pada awal bulan dan menurun seiring bertambahnya umur. Panjang asismtotik (L ) ikan kuniran pada saat penelitian sebesar $21 \mathrm{~cm}$, sedangkan ikan kuniran pada penelitian di Kendari diketahui panjang asismtotik sebesar 18,44 cm (Asriyana \& Nur Irawati, 2017). Nurulludin \& Prihatiningsih, (2014) bahwa panjang L ikan di Perairan Utara Laut Jawa sebesar 15,02 $\mathrm{cm}$. Dugaan panjang asimtotik ikan kuniran di perairan Laut Jawa lebih kecil jika dibandingkan dengan beberapa perairan di Selat Malaka, dikarenakan tekanan penangkapan ikan di Laut Jawa lebih besar. 
Tabel 1. Hasil penelitian ikan kuniran (Upeneus sulphureus) pada beberapa lokasi

Table 1. Monthly percentage recruitment of sulphur goatfish (Upeneus sulphureus)

\begin{tabular}{ccll}
\hline $\mathrm{K}$ & $\mathrm{L} \infty(\mathrm{cm})$ & \multicolumn{1}{c}{ Lokasi } & \multicolumn{1}{c}{ Referensi } \\
\hline 0,65 & 20,22 & Bangladesh & Reuben et al., (1994) \\
0,85 & 17,45 & Irak & Mohamed \& Mutlak, 2006 \\
0,46 & 19,00 & Irak & Mohamed et al., 2008 \\
0,72 & 18,85 & Irak & Mohamed \& Resen, 2010 \\
0,64 & 15,20 & Laut Jawa & Nurulludin \& Prihatiningsih, 2014 \\
1,43 & 17,70 & Laut Jawa & Nugroho et al., 2017 \\
0,80 & 21,00 & Selat Malaka & Penelitian sekarang (Present study) \\
\hline
\end{tabular}

\#

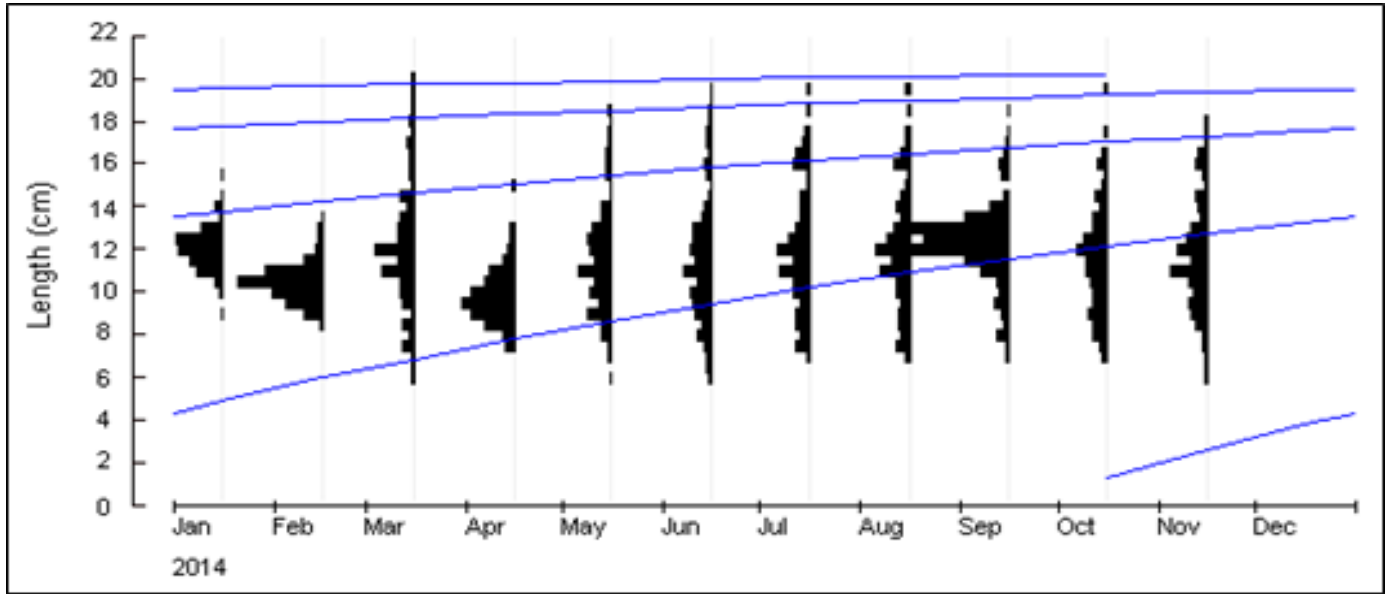

Gambar 3 . Garis pertumbuhan ikan kuniran (Upeneus sulphureus).

Figure 3. The growth curve of sulphur goatfish (Upeneus sulphureus).

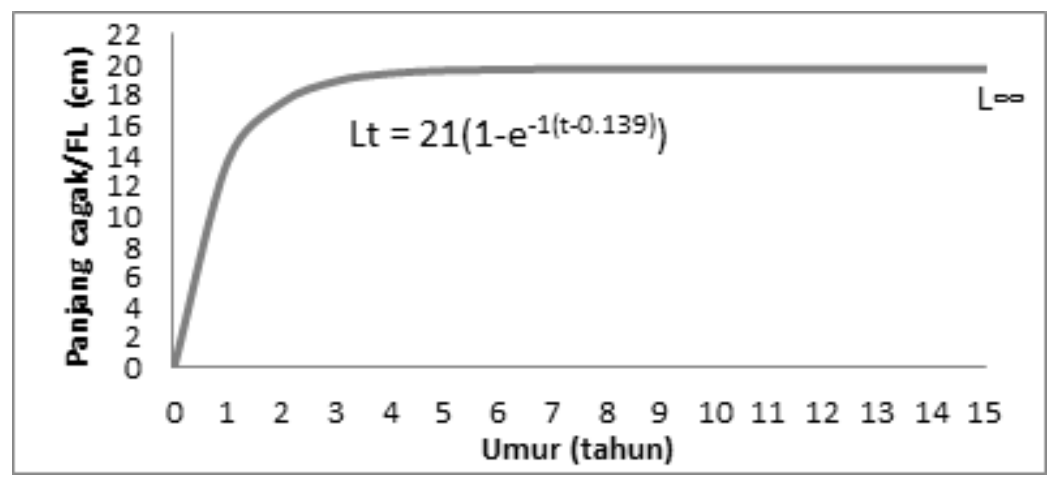

Gambar 4. Kurva pertumbuhan tahunan Von Bertalanffy ikan kuniran (Upeneus sulphureus). Figure 4. Annual growth rate curve Von Bertalanffy of Sulphur goatfish (Upeneus sulphureus).

Kurva hasil tangkap diperoleh dengan menggunakan parameter pertumbuhan ikan kuniran. Berdasarkan nilai parameter yang tersebut diketahui nilai laju kematian total (Z) sebesar 4,24 pertahun, laju kematian alamiah (M) 1,73 pertahun, laju kematian akibat penangkapan (F) 2,51 per tahun, sehingga diperoleh tingkat eksploitasi (E) ikan kuniran di Selat Malaka sebesar 0,59 per tahun. Nilai $F$ yang tinggi mengindikasikan bahwa tekanan penangkapan sudah sangat padat. Tingkat kematian akibat penangkapan berbanding lurus dengan upaya penangkapan dan kemampuan tangkap (Atmaja \& Nugroho, 2004).

Tingkat eksploitasi ikan kuniran (E) di Selat Malaka sebesar 0,59 per tahun. Kondisi ini dapat diartikan bahwa ikan kuniran di selat Malaka telah mengalami lebih tangkap sebesar 9\%. Gulland (1971) dalam Sparre \& Venema (1999) menduga tingkat eksploitasi ikan dikatakan optimal apabila nilai E sama dengan 0,5. Penurunan ikan kuniran diakibatkan oleh penangkapan yang tidak terkontrol (Iswara et al., 2014). Penentuan 
laju eksploitasi merupakan salah satu faktor yang perlu diketahui untuk menentukan kondisi sumberdaya perikanan dalam pengkajian stok ikan (King, 1995).

Pola penambahan baru Upeneus sulphureus di perairan Selat Malaka terjadi hampir setiap bulan. Puncak terjadinya penambahan baru ikan kuniran di Selat Malaka terjadi pada bulan September sebesar $22,68 \%$. Hasil analisa pola penambahan baru ditampilkan pada Gambar 6. Penelitian rekruitmen ikan kuniran dilaporkan bahwa puncak rekruitmen di perairan Barat Laut Teluk Arab terjadi bulan Oktober (Mohamed \& Resen, 2010). Pada beberapa spesies, rekruitmen dapat berupa migrasi dari nursery area yang telah ditentukan. Metode sederhana yang digunakan untuk mengetahui waktu terjadinya rekruitmen yaitu dengan menggambarkan persentase individu yang berukuran kecil dari sampel yang diambil berdasarkan interval kelas stok dewasa (King, 1995). Perkiraan puncak terjadinya penambahan baru dalam populasi ikan kuniran di Selat Malaka diperkirakan terjadi pada akhir musim timur (Juni - Agustus) sampai musim peralihan II (September - Nopember). Hasil prediksi biomassa per penambahan baru secara teoritis menunjukkan semakin menurun seiring dengan bertambahnya jumlah upaya dan semakin kecil ukuran ikan yang tertangkap maka semakin kecil juga biomassa per rekruitnya (Kembaren et al., 2016).

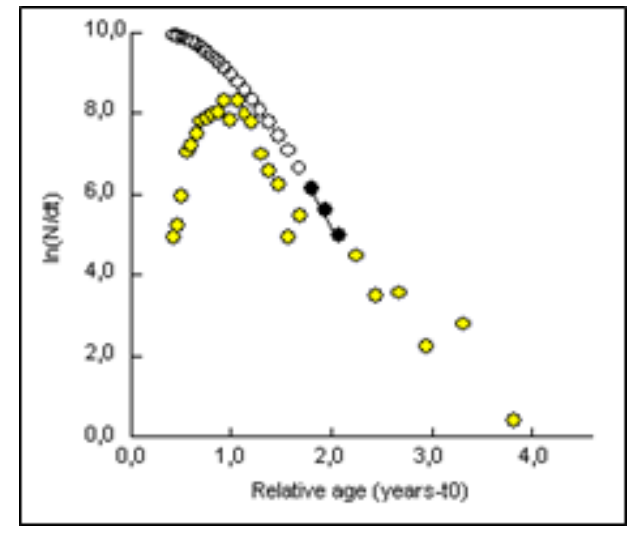

Gambar 5. Kurva penangkapan dan parameter kematian ikan kuniran (Upeneus sulphureus).

Figure 5. The catch curve and mortality parameters of both Sulphur goatfish (Upeneus sulphureus).

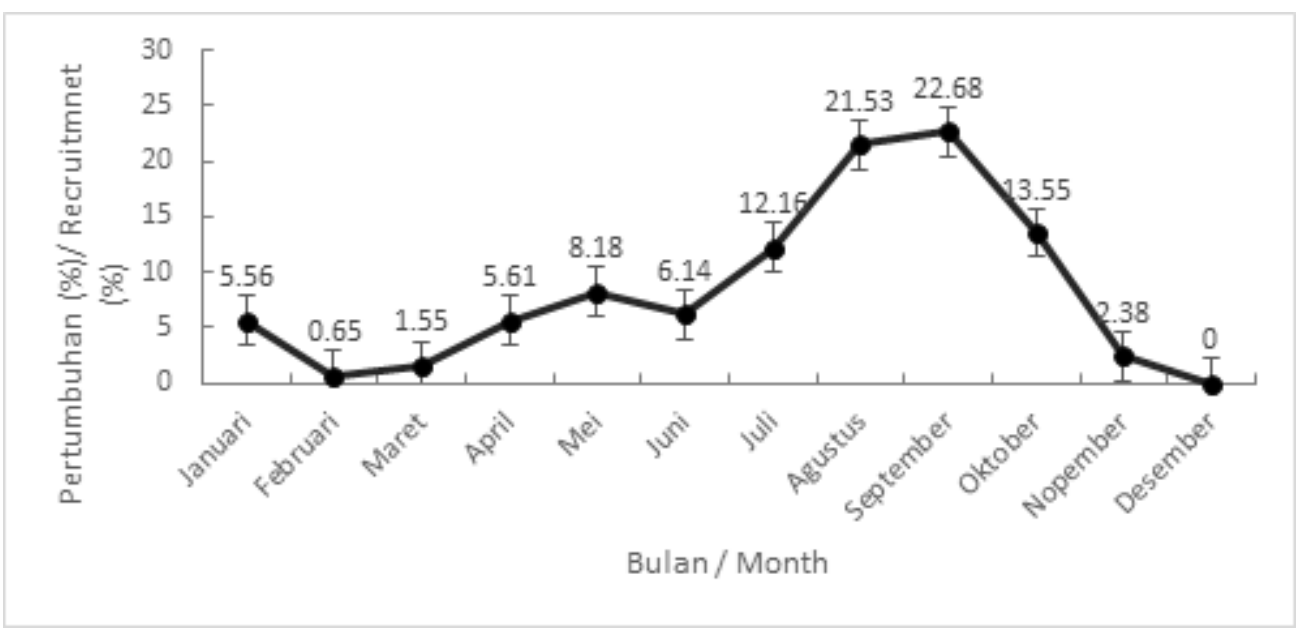

Gambar 6. Persentase bulanan penambahan baru ikan kuniran (Upeneus sulphureus).

Figure 6. Monthly percentage recruitment of sulphur goatfish (Upeneus sulphureus).

\section{KESIMPULAN}

Parameter populasi ikan kuniran di Selat Malaka memiliki koefisien pertumbuhan $(\mathrm{K})$ sebesar 0,80 per tahun dan panjang asimtotik $\left(\mathrm{L}_{\infty}\right)$ sebesar $21,0 \mathrm{~cm}$. Laju mortalitas alami (M) ikan kuniran sebesar 1,73 per tahun dan mortalitas penangkapan (F) sebesar 2,51 per tahun, sehingga diperoleh nilai E 0,59 per tahun. Pemanfaatan ikan kuniran di perairan Selat Malaka sebelum moratorium pelarangan trawl dan sejenisnya dalam kondisi jenuh (Fully exploited). 


\section{PERSANTUNAN}

Tulisan ini merupakan kontribusi dari Kementerian Riset dan Teknologi - Pendidikan Tinggi yang telah mengikutkan penulis dalam program beasiswa Saintek 2018 dan Kegiatan hasil penelitian pengkajian sumberdaya ikan demersal di WPP 571 Selat Malaka Tahun 2014 di Balai Penelitian Perikanan Laut, Jakarta.

\section{DAFTAR PUSTAKA}

Asriyana \& Irawati, N., (2017). Growth Of Gostfish, Upeneus sulphureus In Kendari Bay, Southeast Sulawesi. AQUASAINS. Jurnal IImu Perikanan dan Sumberdaya Perairan. 6 ( 1 ), 527 - 533.

Asriyana, Rahardjo, M. F., Sukimin, S., Lumban Batu, D. F., \& Kartamihardja, E. S. (2009). Keanekaragaman ikan di perairan Teluk Kendari. Jurnal Iktiologi Indonesia, 9(2), 97-112.

Atmaja, S. B., \& Nugroho, D. (2004). Karakteristik parameter populasi ikan siro (Amblygaster sirm) dan model terapan Beverton dan Holt di Laut Natuna dan sekitarnya. Jurnal Penelitian Perikanan Indonesia, 10(4), 21-27.

Azizah, I. R., Rudiyanti, S., \& Ghofar, A. (2015). Komposisi hasil tangkapan cantrang dan aspek biologi ikan kuniran (upeneus sulphureus) yang didaratkan di PPP Bajomulyo, Juwana. Diponegoro Journal of Maquares, 4(4), 33-41

Fahmi, \& Adrim, M. (2002). Fauna ikan demersal di Teluk Kwandang, Kecamatan Kwandang, Kabupaten Gorontalo, Sulawesi Utara. Perairan Sulawesi dan Sekitarnya: Biologi, Lingkungan, dan Oseanografi. Lembaga Ilmu Pengetahuan Indonesia. 19-24.

Hariati, T., Nugroho, D., \& Girsang, S. (2000). Perkembangan armada pukat cincin di selat Malaka. Jurnal Penelitian Perikanan Indonesia, 6(2), 43-51.

Iswara, K. W., Saputra, S. W., \& Solichin, A. (2014). Analisis Aspek Biologi Ikan Kuniran (Upeneus spp) berdasarkan jarak operasi penangkapan alat tangkap cantrang di perairan Kabupaten Pemalang. Diponegoro Journal of Maquares, 3(4), 83-91.

Kembaren, D. D., Ernawati, T., \& Sadhotomo, B (2016). Analisis Hasil Per Penambahan Baru Perikanan Lobster Pasir Panulirus homarus (Linnaeus, 1758) Di Perairan Aceh Barat. Jurnal Penelitian Perikanan Indonesia. 2(2), 61-70

Kembaren, D. D., \& Ernawati, T. (2011). Beberapa aspek biologi ikan kuniran (Upeneus sulphureus) di Perairan Tegal dan Sekitarnya. Bawal Widya Riset Perikanan Tangkap, 3(4), 261-267.

King, M. (1995). Fisheries Biology Assessment and Management. Oxford: Fishing News Books. 341 p.

Mohamed, A. R. M., \& Mutlak, F. M. (2006). Monthly fluctuations of catch rates of three goatfishes species from Khor Al-Amayh, Northwest Arabian Gulf. Marina Mesopotamica Journal, 2l(2), 257-270.

Mohamed, A. R. M., Hussein, S. A., \& Mutlak, F. M. (2008). The growth and stock assessment Upeneus sulphureus in Iraqi marine waters, north west Arabian Gulf. Basrah. Marina Mesopotamica Journal, 7(1), 104-119.

Mohamed, A. R. M., \& Resen, A. K. (2010). The population status of sulphur goatfish (Upeneus sulphureus) in the Iraqi marine waters, Northwest Arabian Gulf. Mesopot Journal Marine Science, 25(1), 31-40.

Nugroho, D., Patria, M. P., Supriatna, J., \& Adrianto, L., (2017). The estimates spawning potential ratio of three dominant demersal fish species landed in Tegal, north coast of Central Java, Indonesia. Biodiversitas journal, 18 (2) : 844-849.

Nurulludin, \& Prihatiningsih. (2014). Parameter populasi dan tingkat eksploitasi ikan kuniran (Upeneus sulphureus) di Laut Jawa. Bawal Widya Riset Perikanan Tangkap, 6 (3), 163-168.

Pauly, D. (1980). On the interrelationships between natural mortality, growth parameters and environmental temperature in 175 fish stock. Journal du Conseil International pour Exploration de la Mer, 39 (3) : 175 - 192

Pavlova, D. A., Emel'yanova, N. G., Thuan, L. T. B., \& Vo Thi Ha. (2014). Reproduction of Freckled Goatfish Upeneus tragula (Mullidae) in the Coastal Zone of Vietnam. Journal of Ichthyology, 54(10), 893-904.

Potier, M., \& Sadhotomo, B. (1991). Sampling training. ALA/INS/87/17. Scien. And Tech. Doc. 4. 29 p

Reuben, S., Vijayakumaran, K., \& Kchittibabus. (1994). Growth, maturity, and mortality of Upeneus sulphureus from Andhra-Orissa coast. Indian Journal of Fisheries, 2, 87-91.

Saputra, S. W., Soedarsono, P., \& Sulistyawati, G. A. (2009). Beberapa aspek biologi ikan kuniran (Upeneus spp.) di perairan Demak. Jurnal Saintek Perikanan, 5(1), 1-6.

Sparre, P., \& Venema, S. C. (1999). Introduksi Pengkajian Stok Ikan Tropis. Buku I: Manual. Food and Agriculture Organisation. UNO. 438 pp.

Sulistiono. (2012). Reproduksi ikan beloso (Glossogobius giuris) di perairan Ujung Pangkah Jawa Timur. J. Akuakultur Indonesia, 11(1):64-75

Sumiono, B., \& Nuraini, S. (2007). Beberapa parameter biologi ikan kuniran (Upeneus sulphureus) hasil tangkapan cantrang yang didaratkan di Brondong, Jawa Timur. Jurnal Iktiologi Indonesia, 7(2): 83 - 88.

Udupa, K. S. (1986). Statistical method of estimating the size of first maturity in fish. Fishbyte. Manila: ICLARM. 4(2) 8-1. 
Parameter populasi dan tingkat pemanfaatan ikan kuniran.... (Nurulludin) 